\title{
Polymorphic heterologous microsatellite loci for population genetics studies of the white-faced ibis Plegadis chihi (Vieillot, 1817) (Pelecaniformes, Threskiornithidae)
}

\author{
Andiara Silos Moraes de Castro e Souza, Carolina Isabel Miño and Silvia Nassif Del Lama \\ Departamento de Genética e Evolução, Universidade Federal de São Carlos, São Carlos, SP, Brazil.
}

\begin{abstract}
We screened 44 heterologous microsatellites isolated in species of the families Threskiornithidae, Ciconiidae and Ardeidae for their use in a migratory waterbird, the white-faced ibis Plegadis chihi (Vieillot, 1817) (Threskiornithidae). Of the screened loci, $57 \%$ amplified successfully and $24 \%$ were polymorphic. In two breeding colonies from southern Brazil ( $\mathrm{N}=131$ ) we detected 32 alleles (2-10 alleles/ locus). Average He over all loci and colonies was 0.55 , and the combined probability of excluding false parents, $98 \%$. There was no departure from HWE in any loci or population. Eru6 and Eru4 loci were in non-random association in the Alvorada colony, and NnNF5 and Eru5 in both populations. AMOVA analysis indicated that most of the genetic diversity was contained within populations. Structure analysis suggested a single population, and $F_{S T}$ value showed weak genetic structuring $\left(F_{S T}=0.009, \mathrm{p}=0.05\right)$. The two populations are apparently connected through gene-flow. The panel of six microsatellites optimized here was sufficiently informative for characterizing the genetic diversity and structure in these natural populations of the white-faced ibis. The information generated could be useful in future studies of genetic diversity, relatedness and the mating system in Plegadis chihi and related species.
\end{abstract}

Key words: cross-species amplification, genetic diversity, molecular markers, white-faced ibis, SSR.

Received: April 11, 2011; Accepted: November 21, 2011.

\section{Introduction}

The white-faced ibis Plegadis chihi (Vieillot, 1817) (Pelecaniformes, Threskiornithidae) is a migratory longlegged wading bird, with a long, downward-curved bill and attractive metallic bronze plumage (Dark-Smiley and Keinath, 2003). Occurring from North to South America, it primarily inhabits freshwater wetlands and marshes, and forages in flooded areas and agricultural fields (Ryder and Manry, 1994). Populations in the U.S.A. nest in marshes in the western region, and winter in large flocks in the western parts of the country and Mexico (Dark-Smiley and Keinath, 2003). In South America, it occurs in Brazil, Bolivia, Paraguay, Uruguay, Argentina and Chile. In Brazil, breeding takes place in colonies in coastal lagoons in Rio Grande do Sul State, in the southernmost part of the country (Petry and Fonseca, 2005). Although flocks engage in regional movements between the breeding and wintering periods, their specific migration routes remain unknown (Ryder and Manry, 1994).

So far, populations of the white-faced ibis have not been investigated as to genetic variability, an important

Send correspondence to Andiara Silos Moraes de Castro e Souza. Departamento de Genética e Evolução, Universidade Federal de São Carlos, Rodovia Washington Luís km 235, 15365-905 São Carlos, SP, Brazil. E-mail: andiara.silos@gmail.com. property of populations. Population-genetic parameters can be determined with the aid of molecular markers, such as microsatellites, also called simple sequence repeats (SSR). DNA sequences, two to six nucleotides long, repeated in tandem and widely dispersed in all eukaryotic genomes (Tautz, 1989). These codominant and highly polymorphic markers (Zane et al., 2002) have high mutation rates $\left(10^{-2}-10^{-6}\right.$ per meiotic event) (Li et al., 2002), the majority being selectively neutral (Selkoe and Toonen, 2006). Accordingly, SSRs have become powerful tools for use in forensic studies, kinship investigation, gene mapping, conservation biology and population genetics (Zane et al., 2002).

In spite of their utility and wide application, there is still a major drawback in the use of microsatellites, since any study aimed at employing such markers requires the isolation of new loci and the development of new primers. However, the isolation of loci for a given species, besides being exceedingly labour-intensive, requires considerable funds, time and technical experience (Mukesh et al., 2011). Moreover, in avian species, the process of microsatellite isolation can pose an additional challenge, since microsatellites are less abundant in avian genomes than in any other vertebrate group (Primmer et al., 1997). An alternative cost-effective approach is the use of primers developed 
for closely related species, denominated cross-species microsatellite amplification or heterologous amplification, commonly applied in bird studies (Barbará et al., 2007; Mukesh et al., 2011). The success of this process depends on the degree of conservation of primer annealing sites among related species. High evolutionary divergence between the species from which the microsatellite loci were originally isolated (the source species) and the species to which they will be applied (the target species) results in a low number of amplified loci (Primmer et al., 2005). A necessary first step in any study involving the use of heterologous markers is the screening and evaluation of their level of polymorphism in the target species.

Microsatellite loci constitute an adequate tool for estimating such important properties of populations, as genetic diversity, population structure, effective population size and gene flow, all useful in defining units for conservation (Haig et al., 2011). This lack of species-specific microsatellite markers is one of the reasons why, in populations of the white-faced ibis, nuclear neutral genetic variability remains neglected. Thus, the goal in the present study was to identify and optimize heterologous microsatellite loci for population studies in this bird-species. Further information is provided on population genetic parameters and patterns of genetic structuring in samples of two breeding colonies located in the extreme geographic distribution of this species in south Brazil.

\section{Material and Methods}

Growing feathers were plucked from 44 nestlings (one per nest) in a breeding colony in Alvorada, Rio Grande

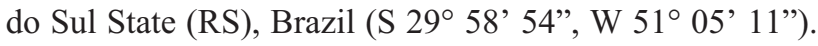
Samples of growing feathers and muscle tissue were also taken from 87 nestlings (one per nest) of a breeding colony in Tapes, RS, Brazil (S $30^{\circ} 41^{\prime} 12^{\prime \prime}, \mathrm{W} 51^{\circ} 23^{\prime} 53^{\prime \prime}$ ). Genomic DNA was extracted from the feathers and muscle tissue as per the standard phenol/chloroform method (Sambrook et al., 1989). Initial screening involved a panel of 44 heterologous microsatellite primers previously isolated in species belonging to the Threskiornithidae and Ardeidae families (order Pelecaniformes), viz., Platalea ajaja (Sawyer, 2002, PhD Thesis, Univ. North Texas), Eudocimus ruber (Santos et al., 2006), Nipponia nippon (Ji et al., 2004), Ardea herodias (McGuire and Noor, 2002) and Bubulcus ibis (Campanini et al., 2010); and to the Ciconiidae family (order Ciconiiformes): Mycteria americana (Tomasulo-Seccomandi et al., 2003).

Polymerase chain reactions (PCR) were carried out in 10-12 $\mu \mathrm{L}$ reaction mixtures containing by $1 \mathrm{x}$ PCR buffer (1 mM Tris-HCL, pH 8.4, $50 \mathrm{mM} \mathrm{KCl}$ ), 1.5-2.5 mM $\mathrm{MgCl}_{2}, 0.2 \mathrm{mM}$ dNTPs (Amersham Biosciences), $0.5 \mathrm{U}$ of Taq DNA polymerase (Biotools B\&M Labs) and 10-30 ng of template DNA. Except for loci isolated in P. ajaja and M. americana (HEX-labeled), all the primers were dynami- cally labeled with HEX, FAM or TET, using M13 methodology (Schuelke, 2000). Reactions were carried out in an Eppendorf Mastercycler Gradient ${ }^{\circledR}$ (Eppendorf AG, Hamburg, Germany) thermal cycler. The annealing temperatures described for the source species were initially tested, and then modified accordingly, in order to increase the probability of amplifying heterologous loci (Primmer et al., 2005). Successful amplification conditions are subsequently described. For Aaju3 and Aaju5 loci (HEXlabeled), the PCR cycling parameters were: 1 min of initial denaturation at $94{ }^{\circ} \mathrm{C}$, followed by 29 cycles of denaturation at $94{ }^{\circ} \mathrm{C}$ for $30 \mathrm{~s}$, annealing at $53{ }^{\circ} \mathrm{C}$ for $35 \mathrm{~s}$ and extension at $72{ }^{\circ} \mathrm{C}$ for $1 \mathrm{~min}$, and a final extension at $72{ }^{\circ} \mathrm{C}$ for $20 \mathrm{~min}$. For the loci NnNF5, NnCE11, NnDD9 and NnHB12 (M13-labeled), conditions were: 4 min of initial denaturation at $94{ }^{\circ} \mathrm{C}$, followed by 38 cycles of denaturation at $94^{\circ} \mathrm{C}$ for $30 \mathrm{~s}$, annealing at $57^{\circ} \mathrm{C}$ for $1 \mathrm{~min}$ and extension at $72{ }^{\circ} \mathrm{C}$ for $30 \mathrm{~s}, 8$ cycles of $94^{\circ} \mathrm{C}$ for $30 \mathrm{~s}, 45 \mathrm{~s}$ at $53{ }^{\circ} \mathrm{C}$ and extension at $72{ }^{\circ} \mathrm{C}$ for $45 \mathrm{~s}$ with a final extension at $72{ }^{\circ} \mathrm{C}$ for $20 \mathrm{~min}$. Eru3, Eru4, Eru6 and Eru9 loci (M-13 labeled) were amplified with the following PCR parameters: 4 min of initial denaturation at $94{ }^{\circ} \mathrm{C}$, followed by 35 cycles of $94{ }^{\circ} \mathrm{C}$ for $45 \mathrm{~s}$, annealing at specific temperature for $35 \mathrm{~s}$ and extension at $72{ }^{\circ} \mathrm{C}$ for $1 \mathrm{~min}, 8$ cycles of $94{ }^{\circ} \mathrm{C}$ for $30 \mathrm{~s}, 45 \mathrm{~s}$ at $53^{\circ} \mathrm{C}$ and extension at $72{ }^{\circ} \mathrm{C}$ for $1 \mathrm{~min}$ with a final extension at $72{ }^{\circ} \mathrm{C}$ for $20 \mathrm{~min}$. Eru2, Eru5, Eru7, Eru8 and Eru11 loci (M-13 labeled) were amplified as follows: initial denaturation at $94{ }^{\circ} \mathrm{C}$ for $3 \mathrm{~min}$, followed by 19 cycles at $94{ }^{\circ} \mathrm{C}$ for $45 \mathrm{~s}$, annealing for $1 \mathrm{~min}$ at locus-specific temperatures and $72{ }^{\circ} \mathrm{C}$ for 1 min, 8 cycles of $94{ }^{\circ} \mathrm{C}$ for $30 \mathrm{~s}, 45 \mathrm{~s}$ at $53{ }^{\circ} \mathrm{C}$ and extension at $72{ }^{\circ} \mathrm{C}$ for $1 \mathrm{~min}$ with a final extension at $72{ }^{\circ} \mathrm{C}$ for $20 \mathrm{~min}$. For WS03, WS04 and WS09 loci (HEX-labeled), amplification conditions were: $5 \mathrm{~min}$ of initial denaturation at $94{ }^{\circ} \mathrm{C}$, followed by 21 cycles of $94^{\circ} \mathrm{C}$ for $30 \mathrm{~s}, 35 \mathrm{~s}$ at $55^{\circ} \mathrm{C}$ and extension at $72{ }^{\circ} \mathrm{C}$ for $1 \mathrm{~min}, 8$ cycles of $94^{\circ} \mathrm{C}$ for $30 \mathrm{~s}, 45 \mathrm{~s}$ at $53^{\circ} \mathrm{C}$ and extension at $72{ }^{\circ} \mathrm{C}$ for 1 min with a final extension at $72^{\circ} \mathrm{C}$ for $20 \mathrm{~min}$. For Bi1, Bi5, Bi7, Bi9, Bi10, Bi1 1 and Bi12 loci (M-13 labeled), PCR parameters were: initial denaturation at $5 \mathrm{~min}$ for $94{ }^{\circ} \mathrm{C}$, followed by 20 cycles of $94{ }^{\circ} \mathrm{C}$ for $30 \mathrm{~s}$, annealing for $1 \mathrm{~min}$ at locus-specific temperatures and extension at $72{ }^{\circ} \mathrm{C}$ for $45 \mathrm{~s}, 15$ cycles of $94{ }^{\circ} \mathrm{C}$ for $30 \mathrm{~s}$, annealing for $1 \mathrm{~min}$ at locus-specific temperatures and extension at $72{ }^{\circ} \mathrm{C}$ for $45 \mathrm{~s}, 12$ cycles of $94{ }^{\circ} \mathrm{C}$ for $30 \mathrm{~s}, 45 \mathrm{~s}$ at $53{ }^{\circ} \mathrm{C}$ and extension at $72{ }^{\circ} \mathrm{C}$ for $45 \mathrm{~s}$ with a final extension at $72{ }^{\circ} \mathrm{C}$ for $20 \mathrm{~min}$.

In order to detect amplification, PCR products underwent horizontal electrophoresis in 1\% agarose gels stained with ethidium bromide. Genotyping was carried out in a MegaBACE 1000 (Amersham Biosciences) automatic sequencer. PCR products were diluted with Tween $0.1 \%$ and added to ET550-R Size Standard (GE Healthcare). Alleles were sized after analyzing electropherograms in MegaBace Fragment Profiler software (GE Healthcare). 
The Micro-Checker (Van Oosterhout et al., 2004) program was applied for assessing genotyping quality, the occurrence of null alleles, allelic dropout and stuttering. The number of alleles $(A)$, expected $(\mathrm{He})$ and observed $(H o)$ heterozygosity, exclusion probability $(P E)$, identify probability $(P I)$, Hardy-Weinberg equilibrium $(H W E)$ per locus, and analysis of molecular variance (AMOVA) were estimated using GenAlex version 6.4 (Peakall and Smouse, 2006). Polymorphic information content (PIC) was computed in Cervus version 3.0 (Kalinowski et al., 2007). Allelic richness $(R a)$, genic diversity $(D G, \mathrm{Nei}, 1987)$, inbreeding coefficient $\left(F_{I S}\right)$ and population differentiation $\left(F_{S T}\right)$ were computed using Fstat version 2.9.3.2 (Goudet, 1995). Linkage disequilibrium $(L D)$ between loci was computed in Arlequin version 3.5.1.2 (Excoffier and Lischer, 2010). $P$-values for all tests were corrected for multiple comparisons using the sequential Bonferroni procedure (Rice, 1989). The Genepop version 4.0.10 program (Rousset, 2008) was applied for computing a multilocus estimate of the effective number of migrants ( $\mathrm{Nm}$ ) (Slatkin, 1985; Slatkin and Barton, 1989). Signals of reduction in population size were assayed with the Wilcoxon test (Luikart et al., 1998), as implemented in Bottleneck version 1.2.02 software (Cornuet and Luikart, 1996). Population structure for microsatellite variation was also examined using the Structure version 2.1 program (Pritchard et al., 2000). By this Bayesian clustering method, estimates are made of the number of genetic clusters (subpopulations; $k$ ) that best explain the data, and thus, based on their genotypes and disregarding sampling locations, assign individuals to subpopulations. Ten replicates of each run for $k=1$ and $k=2$ were carried out using the admixture model with a burn-in period of 100,000, and 10,000 MCMC reps after burn-in.

\section{Results and Discussion}

The 44 loci were initially screened in samples of 20 individuals from each population. Of the loci tested, $19 \mathrm{did}$ not amplify, even after several trials: Aaju1, Aaju2 ( $P$. ajaja), Eru10 (E. ruber), WS8, WS13, WS14, WS18, WS23, WS24 (M. americana), Ah211, Ah217, Ah320, Ah414 (A. herodias) and Bi2, Bi6, Bi8, Bi13, Bi14, Bi15 (B. ibis). Among the remaining 25 that did successfully amplify, six were polymorphic in 40 individuals from the two breeding colonies (Table 1). The percentages of heterologous amplification (57\%) and polymorphic loci (24\%) were slightly lower than those reported in the literature for birds, i.e., average success in amplification from 67\% (Dawson et al., 2000) to 84\% (Galbusera et al., 2000), and polymorphic loci from $39 \%$ (Galbusera et al., 2000) to $46 \%$ (Primmer et al., 1996). All the heterologous loci disclosed as polymorphic in $P$. chihi had already been originally isolated in species of the same family: Threskiornithidae. This is in accordance with the hypothesis that the proportion of polymorphic loci increases with decreasing phylogenetic distance between the source and target species (Primmer $e t$ al., 2005).

At the level of families and orders, the percentages of successful amplification and polymorphism were higher than, or of the same magnitude as, those reported in the literature for the group 'birds'. Herein, when considering loci isolated in other genera of the same family as $P$. chihi, the $84 \%$ of successful heterologous amplification was of the same magnitude as that obtained by Chang et al. (2009) $(81.8 \%)$, and higher than that by Barbará et al. (2007) (62\%), Lopes et al. (2010) (62.5\%), and Yeung et al. (2009) $(17 \%)$. When considering different families of the same order, $57 \%$ success was higher than Li and Merilä (2010) (47.4\%), Yeung et al. (2009) (9\%), Barbará et al. (2007) (38\%), and Miño (2006, Master's Thesis, Universidade Federal de São Carlos, São Carlos, Brazil) (31\%). The percentage of polymorphic loci among those that successfully amplified, when considering co-familial genera, was $40 \%$, whereas Barbará et al. (2007) encountered 55\%. The percentage of polymorphic loci found among families of the same order (24\%) was higher than those found by Li and Merilä (2010) (21.1\%), Barbará et al. (2007) (23\%) and Miño (2006, Master's Thesis, Universidade Federal de São Carlos, São Carlos, Brazil) (15.5\%).

The PIC index, an efficient indicator of loci adequacy in population genetics studies, ranged from 0.35 to 0.76 , with a mean of 0.50 in our panel of microsatellites (Table 1). It is commonly accepted that PIC values $>0.50$ are characteristic of the most useful markers, $0.25<P I C>$ 0.50 of those moderately informative, and $P I C<0.25$ of the less informative (Andres and Kapkowska, 2011). Thus, the loci optimized in this study can thus be considered moderate to highly informative. The potential of our set of markers for identifying individuals within the population was quite high, i.e., across loci $P I=0.0002$ in Alvorada and $P I=0.0001$ in Tapes. Exclusion probability $(P E)$ across loci of $98 \%$ falls within the range observed in other waterbirds (Miño et al., 2009). This relatively high probability of excluding a false parent indicates that this panel of markers is useful not only in the estimation of the overall level of genetic variability in white-faced ibis populations, but also in the diagnosis of relationships between individuals.

Population genetic parameters were estimated using the entire sample ( $\mathrm{N}=44$ for Alvorada; $\mathrm{N}=87$ for Tapes). Analysis with the Micro-Checker program indicated null alleles in Eru6 loci due to homozygote excess in both populations, probably caused by stuttering in the electropherograms. According to Chi-square tests, with sequential Bonferroni correction, there was no departure from $H W E$ in any of the analyzed loci after multiple comparisons (Table 2). Across population samples, the mean number of alleles per locus was 4.83, average $\mathrm{He} 0.55$ and average $\mathrm{Ho}$ 0.57 . Average $R a$ per population was 4.70 in Alvorada and 4.42 in Tapes, whereas mean $D G$ was 0.56 in both populations (Table 2). Inbreeding coefficients $\left(F_{I S}\right)$ did not deviate 
Table 1 - Basic information on the microsatellite markers screened in this study. Summary information on the heterologous microsatellite loci screened in a pooled sample of 20 individuals of the white-faced ibis Plegadis chihi from each of two Brazilian colonies. Superscripts in locus names refer to references of the original primer description and PCR cycling parameters, detailed in the table footnote. An asterisk (*) to locus names indicates polymorphism in the studied sample. AT: Annealing temperature in the original species / in P. chihi. PIC: polymorphic information content, $M L$ : monomorphic locus.

\begin{tabular}{|c|c|c|c|c|c|}
\hline Locus & Repetitive unit & $\mathrm{AT}\left({ }^{\circ} \mathrm{C}\right)$ & $\begin{array}{l}\text { Reverse primer volume }(\mu \mathrm{L}) / \\
\text { concentration }(\mu \mathrm{M}) \text { in PCR }\end{array}$ & $\begin{array}{l}\text { Forward primer volume }(\mu \mathrm{L}) / \\
\text { concentration }(\mu \mathrm{M}) \text { in } \mathrm{PCR}\end{array}$ & PIC \\
\hline Aaju $3^{1^{*}}$ & $(\mathrm{GAT})_{13}$ & $55 / 53$ & $0.6 / 2.5$ & $0.6 / 2.5$ & 0.76 \\
\hline Aaju $5^{1}$ & $(\mathrm{GAT})_{16}(\mathrm{TAT})_{4}$ & $58 / 55$ & $0.6 / 2.6$ & $0.6 / 2.6$ & ML \\
\hline $\mathrm{NnNF}^{2 *}$ & $(\mathrm{TAGA})_{2} \mathrm{TA}(\mathrm{CA})_{8}$ & $57 / 57$ & $1.0 / 0.4$ & $2.5 / 10.5$ & 0.35 \\
\hline $\mathrm{NnCE} 11^{2}$ & $(\mathrm{CTG})_{8}$ & $59 / 56$ & $0.8 / 4.0$ & $0.2 / 1.0$ & ML \\
\hline $\mathrm{NnDD} 9^{2}$ & $(\mathrm{GT})_{8}$ & $59 / 54$ & $0.8 / 4.0$ & $0.2 / 1.0$ & ML \\
\hline $\mathrm{NnHB} 12^{2}$ & $(\mathrm{CAT})_{7}$ & $59 / 56$ & $0.8 / 4.0$ & $0.2 / 1.0$ & ML \\
\hline Eru $^{3^{*}}$ & $(\mathrm{GA})_{7}(\mathrm{~A})_{4}(\mathrm{GA})_{10}$ & $53 / 53$ & $0.8 / 4.0$ & $0.2 / 1.0$ & 0.38 \\
\hline Eru $^{3}$ & $(\mathrm{AG})_{21}$ & $53 / 53$ & $0.5 / 2.5$ & $1.25 / 6.25$ & ML \\
\hline Eru $4^{3 *}$ & $(\mathrm{TC})_{11}(\mathrm{C})_{3}(\mathrm{TC})_{9}$ & $62.5 / 54$ & $0.5 / 2.5$ & $1.25 / 6.25$ & 0.37 \\
\hline Eru $5^{3 *}$ & $(\mathrm{CA})_{15}(\mathrm{AT})_{2}(\mathrm{CA})_{3}$ & $65 / 62$ & $0.8 / 4.0$ & $0.2 / 1.0$ & 0.53 \\
\hline Eru $^{3^{*}}$ & $(\mathrm{CT})_{20}$ & $57 / 54$ & $0.5 / 2.5$ & $1.25 / 6.25$ & 0.59 \\
\hline Eru $7^{3}$ & $(\mathrm{CT})_{6} \mathrm{AG}(\mathrm{CT})_{6} \mathrm{TC}(\mathrm{CT})_{10}$ & $62.5 / 60$ & $0.8 / 4.0$ & $0.2 / 1.0$ & ML \\
\hline Eru $8^{3}$ & $(\mathrm{GA})_{8} \mathrm{GCAAGT}(\mathrm{GA})_{9}$ & $63 / 63$ & $0.8 / 4.0$ & $0.2 / 1.0$ & ML \\
\hline $\operatorname{Eru} 9^{3}$ & $(\mathrm{GA})_{24}$ & $62.5 / 54$ & $0.5 / 2.5$ & $1.25 / 6.25$ & ML \\
\hline Eru $11^{3}$ & $(\mathrm{GAAGA})_{18}$ & $62.5 / 63$ & $0.8 / 4.0$ & $0.2 / 1.0$ & ML \\
\hline $\mathrm{WS}^{4}$ & $(\mathrm{AG})_{10}$ & $60 / 58$ & $0.8 / 4.0$ & $0.8 / 4.0$ & ML \\
\hline $\mathrm{WS} 4^{4}$ & $(\mathrm{GT})_{15}$ & $60 / 58$ & $0.8 / 4.0$ & $0.8 / 4.0$ & ML \\
\hline $\mathrm{WS} 9^{4}$ & $(\mathrm{AAC})_{7}$ & $60 / 58$ & $0.8 / 4.0$ & $0.8 / 4.0$ & ML \\
\hline $\mathrm{Bi}^{5}$ & $(\mathrm{GT})_{11}$ & $57 / 57$ & $0.8 / 4.0$ & $0.2 / 1.0$ & ML \\
\hline $\mathrm{Bi} 5^{5}$ & $(\text { TTTG })_{4}$ & $56 / 54$ & $0.8 / 4.0$ & $0.2 / 1.0$ & ML \\
\hline $\mathrm{Bi}^{5}$ & $(\mathrm{TA})_{5}$ & $56 / 52$ & $0.8 / 4.0$ & $0.2 / 1.0$ & ML \\
\hline $\mathrm{Bi} 9^{5}$ & $(\mathrm{CT})_{4}(\mathrm{TTC})_{2}(\mathrm{TC})_{4}$ & $58 / 58$ & $0.8 / 4.0$ & $0.2 / 1.0$ & ML \\
\hline $\operatorname{Bi1} 10^{5}$ & $(\mathrm{AC})_{5} \mathrm{AA}(\mathrm{AC})_{4}$ & $58 / 54$ & $0.8 / 4.0$ & $0.2 / 1.0$ & ML \\
\hline $\mathrm{Bi} 11^{5}$ & $(\mathrm{GT})_{4}$ & $60 / 55$ & $0.8 / 4.0$ & $0.2 / 1.0$ & ML \\
\hline $\mathrm{Bi} 12^{5}$ & $(\mathrm{CA})_{4}(\mathrm{TC})_{2}$ & $59 / 59$ & $0.8 / 4.0$ & $0.2 / 1.0$ & ML \\
\hline
\end{tabular}

Source species: ${ }^{1}$ Platalea ajaja (Sawyer, 2002, PhD Thesis, Univ. North Texas); ${ }^{2}$ Nipponia nippon (Ji et al., 2004); ${ }^{3}$ Eudocimus ruber (Santos et al., 2006); ${ }^{4}$ Mycteria americana (Tomasulo-Seccomandi et al., 2003); ${ }^{5}$ Bubulcus ibis (Campanini et al., 2010).

significantly from random mating $(\mathrm{p}=0.004)$, neither per locus nor population. The exact test of $L D$ indicated association $(\mathrm{p}<0.05)$ between Eru6 and Eru4 loci in the Alvorada colony, and between NnNF5 and Eru5 loci in both populations. Thus, NnNF5 and Eru6 loci were excluded when subsequently estimating population genetic parameters.

Overall expected heterozygosity observed in the white-faced ibis (He: 0.55$)$ was similar to that observed in 17 species of aquatic birds ( $\mathrm{He}: 0.62 \pm 0.15$ ). This $\mathrm{He}$ value was higher than the range of most common heterozygosity values (He: 0.40-0.50) observed in 17 aquatic bird species (Eo et al., 2011), besides being higher than that observed in the wood stork, of the same magnitude as that noted in the jabiru stork (Jabiru mycteria), and lower than in the roseate spoonbill and great egret (Table 3). Furthermore, on considering only the aquatic species phylogenetically more related to the white-faced ibis (the great cormorant,
Phalacrocorax carbo, and the great blue heron, Ardea herodias), mentioned in the Eo et al. (2011) study, it can be seen that in the white-faced ibis, He values were lower (Table 3). Moreover, the mean number of alleles per locus observed in the white-faced ibis $(A: 4.83)$ was lower than the average for the 17 former mentioned species examined by Eo et al. (2011) (A: $6.59 \pm 6.94)$.

According to the Bottleneck program, there was no evidence of recent reduction in size in either of the two reproductive colonies (Wilcoxon test, Alvorada: $\mathrm{p}=0.43$; Tapes: $\mathrm{p}=0.10)$. Population differentiation analysis revealed low, but significant interpopulation genetic structuring $\left(F_{\mathrm{ST}}=0.009, \mathrm{p}<0.05\right)$. According to AMOVA analysis, most genetic variation at the microsatellite locus level $(98 \%)$ was among individuals within populations, whereas only $2 \%(p=0.054)$ of variation was interpopulational. According to Bayesian analysis, both samples can be consi- 
Table 2 - Levels of genetic diversity in Plegadi chihi. Population genetic parameters for two Brazilian breeding-colonies of the white-faced ibis, estimated based on six heterologous microsatellite loci. $N$ : Number of samples genotyped, Ho: Observed heterozygosity, He: Expected heterozygosity, $R a$ : Allelic richness, $P_{H W E}$ : Probability values for tests of departure from Hardy-Weinberg Equilibrium, $D G$ : Gene diversity, $F_{I S}$ : Inbreeding coefficient.

\begin{tabular}{llccccccc}
\hline Colony & Locus & $N$ & $H_{O}$ & $H e$ & $R a$ & $P_{H W E}$ & $D G$ & $F_{I S}$ \\
\hline \multirow{2}{*}{ Alvorada } & Aaju3 & 44 & 0.77 & 0.72 & 8.83 & 0.85 & 0.72 & 0.87 \\
& Eru2 & 37 & 0.49 & 0.39 & 4.00 & 0.70 & 0.39 & 1.00 \\
& Eru4 & 44 & 0.54 & 0.50 & 2.84 & 0.58 & 0.50 & 0.76 \\
& Eru5 & 44 & 0.73 & 0.63 & 3.00 & $0.04^{1}$ & 0.64 & 0.91 \\
& Eru6 & 44 & 0.48 & 0.64 & 7.50 & 0.10 & 0.65 & 0.004 \\
& NnNF5 & 44 & 0.50 & 0.42 & 2.00 & 0.18 & 0.42 & 0.96 \\
& Mean & - & 0.58 & 0.55 & 4.70 & 0.41 & 0.56 & 0.86 \\
\hline \multirow{2}{*}{ Tapes } & Aaju3 & 87 & 0.84 & 0.78 & 9.37 & 0.11 & 0.78 & 0.95 \\
& Eru2 & 84 & 0.56 & 0.44 & 2.69 & 0.06 & 0.44 & 1.00 \\
& Eru4 & 87 & 0.46 & 0.53 & 3.48 & 0.34 & 0.53 & 0.11 \\
& Eru5 & 86 & 0.55 & 0.59 & 3.00 & 0.06 & 0.59 & 0.20 \\
& Eru6 & 86 & 0.51 & 0.60 & 6.00 & 0.06 & 0.60 & 0.02 \\
& NnNF5 & 84 & 0.44 & 0.40 & 2.00 & 0.39 & 0.40 & 0.86 \\
& Mean & - & 0.56 & 0.56 & 4.42 & 0.17 & 0.56 & 0.54 \\
& Overall & - & 0.57 & 0.55 & 4.56 & 0.29 & 0.56 & 0.60 \\
mean & & & & & & & \\
\hline
\end{tabular}

${ }^{1}$ Non-significant after sequential Bonferroni correction $(\mathrm{p}>0.05)$.

Table 3 - Heterozygosity in seven aquatic-bird species. Comparison of average expected heterozygosity $\left(H_{E}\right)$ values observed in seven species of aquatic birds analyzed using microsatellite markers.

\begin{tabular}{|c|c|c|}
\hline Species & $H_{E}$ & Reference \\
\hline Wood stork (Mycteria americana) & 0.37 & Miño et al., $2011^{1}$ \\
\hline Wood stork (Mycteria americana) & 0.44 & $\begin{array}{l}\text { Van Den Bussche } \\
\text { et al., } 1999^{1}\end{array}$ \\
\hline White-faced Ibis (Plegadis chihi) & 0.55 & This study \\
\hline Jabiru stork (Jabiru mycteria) & 0.55 & Lopes et al., 2010 \\
\hline Great egret (Ardea alba) & 0.58 & Miño et al., 2011 \\
\hline Great Blue Heron (Ardea herodias) & 0.59 & Eo et al., $2010^{2}$ \\
\hline Roseate spoonbill (Platalea ajaja) & 0.61 & Miño et al., 2011 \\
\hline Great Cormorant (Phalacrocorax carbo) & 0.73 & Eo et al., $2010^{3}$ \\
\hline
\end{tabular}

${ }^{1}$ The study by Miño et al. (2011) refers to nine microsatellite loci, whereas that by Van Den Bussche et al. (1999) refers to four loci, also mentioned in Eo et al. (2010).

${ }^{2}$ Original reference: McGuire and Noor (2002).

${ }^{3}$ Original references: Goostrey et al. (1998) and Piertney et al. (1998).

dered as a single population cluster. This is in agreement with the estimated number of migrants per generation $(\mathrm{Nm}=1.7)$ and indicates that gene flow may be occurring between the studied populations. In theory, the migration of one individual per generation is sufficient to homogenize the genetic pools of two different populations (Hartl and Clark, 1989). Thus, the low significant differentiation de- tected between these two white-faced ibis colonies is probably a consequence of minor genetic divergence. It must be stressed that a study with more representative samples, collected throughout the entire species-distribution range, using additional microsatellite loci, would help to clarify this issue.

In conclusion, the panel of heterologous loci optimized in this study is suitable for future investigations on genetic structure and relatedness in both natural and captive populations of the white-faced ibis. Future studies including additional loci and populations, should be carried out in order to characterize overall genetic structuring of breeding colonies distributed throughout Brazil. We believe that the data herein would be useful for studies on important questions regarding population genetics, mating systems and kinship in the white-faced ibis and related species. More specifically, the information provided in the present study can benefit studies of population genetics in other species within the genus Plegadis, viz., $P$. falcinellus and $P$. ridgwayi.

\section{Acknowledgments}

We are extremely grateful to Mr. Scherezino Sherer for collecting all the samples from Rio Grande do Sul and to IBAMA/CEMAVE for bird-sampling permission (226631). This study was supported by an MSc scholarship from CNPq to ASMCS (135235/2008-1) and by project research grants from FAPESP to SNDL (2004/15205-8; 2010/50406-5). CIM especially acknowledges support from CAPES (PRODOC project no. 004515/2010). We are also grateful to lab members that read earlier versions of this manuscript.

\section{References}

Andres K and Kapkowska E (2011) Applicability of anatid and galliform microsatellite markers to the genetic diversity studies of domestic geese (Anser anser domesticus) through the genotyping of the endangered zatorska breed. BMC Res Notes 4:e65.

Barbará T, Palma-Silva C, Paggi GM, Bered F, Fay MF and Lexer C (2007) Cross-species transfer of nuclear microsatellite markers: Potential and limitations. Mol Ecol 16:3759-3767.

Campanini EB, Moralez-Silva E and Del Lama SN (2010) Isolamento de marcadores microssatélites em populações brasileiras de Bubulcus ibis (Ciconiiformes, Ardeidae). Resumos do $56^{\circ}$ Congresso Brasileiro de Genética, Guarujá, pp 78.

Chang Q, Xie Z, Li Q and Zhou K (2009) Microsatellite loci developed for black-crowned night-heron (Nycticorax nycticorax) and their cross-amplifications in Ardeidae. Conserv Genet 10:1537-1539.

Cornuet JM and Luikart G (1996) Description and power analysis of two tests for detecting recent population bottlenecks from allele frequency data. Genetics 144:2001-2014.

Dawson A, Hanotte O, Greig C, Stewart IR and Burke T (2000) Polymorphic microsatellites in the blue tit Parus caeruleus 
and their cross-species utility in 20 songbird families. Mol Ecol 9:1941-1944.

Eo SH, Doyle JM and DeWoody JA (2011) Genetic diversity in birds is associated with body mass and type. J Zool 283:220-226.

Excoffier L and Lischer HEL (2010) Arlequin suite ver 3.5: A new series of programs to perform population genetics analyses under Linux and Windows. Mol Ecol Resour 10:564567.

Galbusera P, Van Dongen S and Matthysen E (2000) Crossspecies amplification of microsatellite primers in passerine birds. Conserv Genet 1:163-168.

Goudet J (1995) FSTAT ver. 1.2: A computer program to calculate F-statistics. J Hered 86:485-486.

Goostrey A, Carss DN, Noble LR and Piertney SB (1998) Population introgression and differentiation in the great cormorant Phlacrocorax carbo in Europe. Mol Ecol 7:329-338.

Haig SM, Bronaugh WM, Crowhurst RS, D'Elia J, Eagles-Smith CA, Epps CW, Knaus B, Miller MP, Moses ML, OylerMcCance S, et al. (2011) Genetic applications in avian conservation. Auk 128:205-229.

Hartl DL and Clark AG (1989) Principles of Population Genetics. 2nd edition Sinauer Ass. Inc. Sunderland, Massachusetts, $682 \mathrm{pp}$.

Ji YJ, Liu Y, Ding C and Zhang D (2004) Eight polymorphic microsatellite loci for the critically endangered crested ibis, Nipponia nippon (Ciconiiformes, Threskiornithidae). Mol Ecol Notes 4:615-617.

Kalinowski ST, Taper ML and Marshall TC (2007) Revising how the computer program Cervus accommodates genotyping error increases success in paternity assignment. Mol Ecol 16:1099-1106

Li M and Merilä J (2010) Avian Z-specific microsatellites map to pseudoautosomal or autosomal chromosomes in the Siberian jay (Perisoreus infaustus): Insights into avian genome evolution from cross-species amplification tests. J Genet 89:223-228.

Li YC, Korol AB, Fahima T, Beiles A and Nevo E (2002) Microsatellites: Genomic distribution, putative functions and mutational mechanisms: A review. Mol Ecol 11:2453-2465.

Lopes IF, Haig SM and Del Lama SN (2010) Genetic characterization of Neotropical Jabiru storks: Insights for conservation. Waterbirds 33:425-437.

Luikart G, Allendorf FW, Cornuet JM and Sherwin WB (1998) Distortion of allele frequency distributions provides a test for recent population bottlenecks. J Hered 89:238-247.

McGuire HL and Noor MAF (2002) Microsatellite loci for great white herons and great blue herons (Aves, Ardeidae, Ardea herodias). Mol Ecol Notes 2:170-172.

Miño CI, Sawyer GM, Benjamin RC and Del Lama SN (2009) Parentage and relatedness in captive and natural populations of the Roseate Spoonbill (Aves, Ciconiiformes) based on microsatellite data. J Exp Zool A 311:453-464.

Miño CI, Russelo MA, Gonçalves PFM and Del Lama SN (2011) Reconstructing genetic mating systems in the absence of parental information in colonially breeding waterbirds. BMC Evol Biol 11:e196.

Mukesh T, Rai ID, Mandhan RP and Sathyakumar S (2011) A panel of polymorphic microsatellite markers in Himalayan monal Lophophorus impejanus developed by cross-species amplification and their applicability in other Galliformes. Eur J Wildl Res 57:983-989.

Nei M (1987) Molecular Evolutionary Genetics. Columbia University Press, New York, 512 pp.

Peakall R and Smouse PE (2006) GENALEX 6: Genetic analysis in Excel: Population genetic software for teaching and research. Mol Ecol Notes 6:288-295.

Petry MV and Fonseca VS (2005) Breeding success of the colonist species Bubulcus ibis (Linnaeus, 1758) and four native species. Acta Zool 86:217-221.

Piertney SB, Goostrey A, Dallas JF and Carss DN (1998) Highly polymorphic microsatellite markers in the great cormorant Phalacrocorax carbo. Mol Ecol 7:138-140.

Primmer CR, Moller AP and Ellegren H (1996) A wide range survey of cross-species microsatellite amplification in birds. Mol Ecol 5:365-378.

Primmer CR, Raudsepp T, Chowdhary BP, Møller AP and Ellegren $H$ (1997) Low frequency of microsatellites in the avian genome. Genome Res 7:471-482.

Primmer CR, Painter JN, Koskinen MT, Palo JU and Merilä J (2005) Factors affecting avian cross-species microsatellite amplification. J Avian Biol 36:348-360.

Pritchard JK, Stephens P and Donnelly P (2000) Inference of population structure using multilocus genotype data. Genetics 155:945-959.

Rice WR (1989) Analyzing tables of statistical tests. Evolution 43:223-225.

Rousset F (2008) Genepop'007: A complete reimplementation of the Genepop software for Windows and Linux. Mol Ecol Resour 8:103-106.

Ryder RA and Manry DE (1994) White-faced Ibis (Plegadis chihi). In: Poole, A and Gill, F (eds) The Birds of North America. No. 130. The Academy of Natural Sciences, Philadelphia, and The American Ornithologists Union, Washington, D.C. 24 pp.

Sambrook J, Fritsch EF and Maniatis T (1989) Molecular Cloning: A Laboratory Manual. 2nd edition. Cold Spring Harbour Laboratory Press, New York.

Santos MS, Gonçalves EC, Barbosa MSR, Silva A and Schneider MPC (2006) Isolation and characterization of polymorphic microsatellite loci in the scarlet ibis (Eudocimus ruber Threskiornithidae - Aves). Mol Ecol Notes 6:307-309.

Schuelke M (2000) An economic method for the fluorescent labeling of PCR fragments. Nat Biotechnol 18:233-234.

Selkoe KA and Toonen RJ (2006) Microsatellites for ecologists: A practical guide to using and evaluating microsatellite markers. Ecol Lett 9:615-629.

Slatkin NM (1985) Gene flow in natural populations. Annu Rev Ecol Syst 16:393-430.

Slatkin M and Barton NH (1989) A comparison of three methods for estimating average levels of gene flow. Evolution 43:1349-1368.

Tautz D (1989) Hypervariability of simple sequences as a general source for polymorphic markers. Nucleic Acids Res 17:6463-6471.

Tomasulo-Seccomandi M, Schable NA, Lawrence ABJ, Lehr IBJ, Del Lama SN and Glenn TC (2003) Development of microsatellite DNA loci from the wood stork (Aves, Ciconiidae, Mycteria americana). Mol Ecol Notes 3:563-566. 
Van Den Bussche RA, Harmon SA, Baker RJ, Bryan ALJ, Rodgers JAJ, Harris MJ and Brisbin ILJ (1999) Low levels of genetic variability in North American populations of the Wood Stork (Mycteria americana). Auk 116:1083-1092.

Van Oosterhout C, Hutchinson WF, Wills DPM and Shipley P (2004) MICRO-CHECKER: Software for identifying and correcting genotyping errors in microsatellite data. Mol Ecol 4:535-538.

Yeung CKL, Hsu Y, Yao C and Li S (2009) Isolation and characterization of 23 microsatellite loci in the black-faced spoonbill (Platalea minor) and amplification in other Ciconiiformes waterbirds. Conserv Genet 10:10811084.

Zane L, Bargelloni L and Patarnello T (2002) Strategies for microsatellite isolation: A review. Mol Ecol 11:1-16.

\section{Internet Resources}

Dark-Smiley D and Keinath DA (2003) Species assessment for White-faced ibis (Plegadis chihi) in Wyoming. United States Department of the Interior Bureau of Land Management Wyoming, State Office Cheyenne, Wyoming. Available at: http://www.uwyo.edu/wynddsupport/docs/Reports/SpeciesAssessments/White-faced $\% 20 \mathrm{Ibis} \% 20-\% 20 \mathrm{~F}$ inal\%20(Dec\%202003).pdf.

Associate Editor: Fabrício Rodrigues dos Santos

License information: This is an open-access article distributed under the terms of the Creative Commons Attribution License, which permits unrestricted use, distribution, and reproduction in any medium, provided the original work is properly cited. 